\title{
Vegetation Typology ON LANd USE in SuPPOrTing Surakarta City SUSTAINABLE DEVELOPMENT
}

\section{Tipologi Tutupan Vegetasi Pada PemanfaAtan LaHan UntUK Mendukung Pembangunan Kota Surakarta yang Berkelanjutan}

\author{
Erma Fitria Rini ${ }^{1 *}$, Rufia Andisetyana Putri ${ }^{2}$, Dara Sinta Nugraheni ${ }^{3}$ \\ Urban and Regional Planning Study Program, Engineering Faculty, UNS ${ }^{1 *}$ \\ ermafitria.plano@gmail.com \\ Urban and Regional Planning Study Program, Engineering Faculty, UNS ${ }^{2}$ \\ Urban and Regional Planning Study Program, Engineering Faculty, UNS ${ }^{3}$
}

\begin{abstract}
Green open spaces have natural elements and structures that carry out their ecological and aesthetical roles. The population density of Surakarta City is 11675 people/km ${ }^{2}$, which has an impact on the environment, such as the declining in urban air quality. Urban air quality can be overcome by providing sufficient vegetation. The availability of green open space in Surakarta City until 2014 only reached $12.4 \%$, which means it has not been able to meet the minimum requirement of green open space, including vegetation in it. The method used in this study is descriptive analysis with primary data and satellite imagery. Vegetation studied is not only on public green open spaces, but also on the private green open spaces. The results show that the highest dominance of land use in Surakarta City is the trade and services. Unfortunately, this is inversely proportional to the existing average availability of vegetation cover in the domination, which only reaches $7 \%$. This can be a recommendation for the government in prioritizing the development of green open spaces on those trade and services land use so it can support the sustainable development of Surakarta City.
\end{abstract}

Keywords: land use, vegetation

\section{PENDAHULUAN}

Pembangunan kota yang berkelanjutan salah satunya didukung oleh aspek ekologis kota berupa ruang terbuka hijau. Ruang terbuka hijau adalah bagian dari ruang terbuka sebagai ruang maupun lahan yang memiliki unsur dan struktur alami yang menjalankan perannya secara ekologis dalam mengendalikan udara, tata air, iklim, ameliorasi dan peran lainnya (Joga dan Ismaun, 2011). Selain dari segi ekologis, peran ruang terbuka hijau lainnya adalah sebagai estetika kota dalam bentuk taman, hutan kota, jalur hijau. Hal tersebut menurut tipologi ruang terbuka hijau yang dilihat dari segi fungsinya.

Sedangkan tipologi ruang terbuka hijau lainnya dilihat dari fisik terdapat ruang terbuka hijau alami dan non alami. Apabila dilihat dari segi bentuk, membentuk area/kawasan dan jalur/koridor. Ruang terbuka hijau dilihat dari segi kepemilikan terdapat kepemilikan secara publik yaitu pemerintah yang memiliki hak atas ruang terbuka hijau tersebut dan kepemilikan secara privat yaitu yang ada di atas lahan perseorangan atau pun swasta (Joga dan Ismaun, 2011).

Semakin bertambahnya penduduk dengan kepadatan Kota Surakarta yaitu 11.675 jiwa/km² (Kota Surakarta dalam Angka, 2017), berbanding lurus dengan berbagai jenis aktivitas yang dilakukan seperti kegiatan di jalan raya yaitu lalu lintas kendaraan, aktivitasi industri, rumah tangga, dan lainnya. Hal ini 
menimbulkan dampak menurunnya kualitas lingkungan.

Salah satu upaya menangani dampak penurunan kualitas lingkungan adalah dengan keberadaan ruang terbuka hijau. Proses fotosintesis yang dilakukan tutupan vegetasi dapat mereduksi kadar karbon dioksida di udara dan menghasilkan oksigen yaitu udara yang lebih bersih (Kusminingrum, 2008). Hal tersebut merupakan cara tepat menanggulangi permasalahan lingkungan di perkotaan.

Kota yang sehat, bersih dari polusi udara, dan berkelanjutan sangat membutuhkan peran dari ruang terbuka hijau. Penyediaanruang terbuka hijau dapat berupa taman kota, hutan kota, jalur hijau di kanan kiri jalan, lapangan rumput, serta green roof.

Ketersediaan ruang terbuka hijau berupa taman kota, lapangan, jalur hijau jalan, TPU, sempadan sungai, taman balai sungai, taman bekas TPS, hutan kota, tanah kosong diperuntukan, dan taman kelurahan tahun 2014 baru mencapai 12,74 persen (Dinas Lingkungan Hidup Kota Surakarta, 2015). Sedangkan perencanaan kota harus menyediakan pemanfaatan ruang terbuka hijau dengan luas minimal 30\% dari luas wilayah kota.

Tanpa adanya ruang terbuka hijau yang belum mencukupi maka berpotensi akan terjadi kerusakan lingkungan perkotaan dan suplai oksigen pun semakin berkurang. Tidak seimbangnya ruang terbuka hijau yang dimiliki dengan tingginya zat pencemar udara akan banyak menimbulkan permasalahan dan mengganggu kenyamanan hidup dan kesehatan manusia.

Menurut Peraturan Daerah Nomor 1 Tahun 2012 tentang RTRW Kota Surakarta tahun 2011-2031 strategi pengembangan kawasan lindung yang diharapkan adalah menjaga dan mengembalikan fungsi kawasan lindung salah satunya ruang terbuka hijau dari dampak kerusakan lingkungan.

Pentingnya keberadaan ruang terbuka hijau juga harus disesuaikan dengan pemanfaatan lahan yang ada. Karena pada setiap pemanfaatan lahan memiliki dampak penurunan lingkungan yang berbeda pula sehingga perlakuan terhadap ruang terbuka hijaunya pun berbeda.

Maka dari itu diperlukan penelitian ini untuk mengetahui tipologi ketersediaan ruang terbuka hijau eksisting di tiap aktivitas pemanfaatan lahan.

\section{METODE PENELITIAN}

Metode penelitian yang dilakukan yaitu menggunakan analisis desktriptif. Proses pengumpulan data yang dilakukan adalah dengan survey data primer atau observasi lapangan dan mengamati dengan menggunakan citra satelit. Urutan metode yang dilakukan adalah mengidentifikasi terlebih dahulu pemanfaatan lahan yang ada di Kota Surakarta. Sebelum melakukan observasi lapangan, peneliti mengecek persebaran tutupan vegetasi menggunakan citra satelit yang kemudian dilakukan crosscheck data dengan pengamatan langsung di lapangan dan diidentifikasi berdasarkan tipologi pemanfaatan lahan. Data yang akan diobservasi secara langsung adalah dalam bentuk persentase luasan tutupan vegetasi pohon, semak, rumput, dan sawah yang ada di Kota Surakarta.

\section{HASIL DAN PEMBAHASAN}

\subsection{Identifikasi Pemanfaatan Lahan}

Dalam penelitian ini peneliti mengelompokkan zona yang ada di Surakarta menjadi 5 zona dan sub zona di dalamnnya yaitu zona industri, zona perdagangan dan jasa dengan sub zona perdagangan dan jasa tunggal dan perdagangan dan jasa deret, zona perlindungan setempat dengan sub zona sempadan sungai, zona perumahan dengan sub zona permukiman padat rendah, permukiman padat sedang, dan permukiman padat tinggi, dan zona ruang terbuka dengan sub zona ruang terbuka hijau, makam, dan sempadan jalan arteri.

Masing-masing pemanfaatan lahan dibatasi berdasarkan batas administratif yaitu kecamatan dan kelurahan. Berikut merupakan proporsi pemanfaatan lahan yang ada di Kota Surakarta:

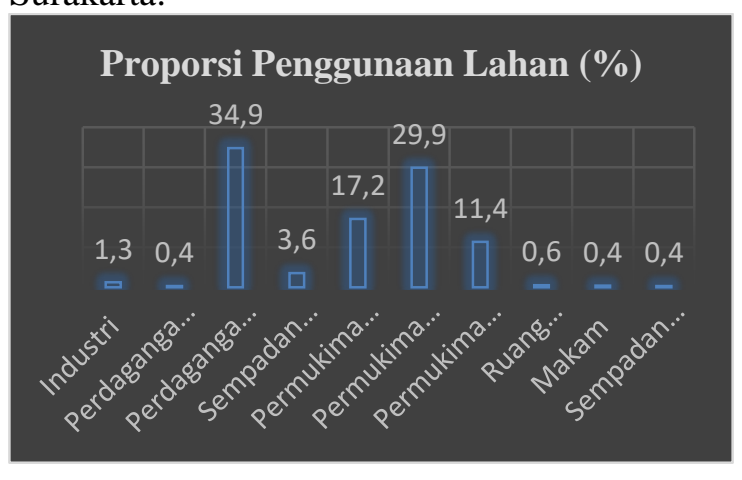


Gambar 1. Persentase Pemanfaatan Lahan di Kota Surakarta

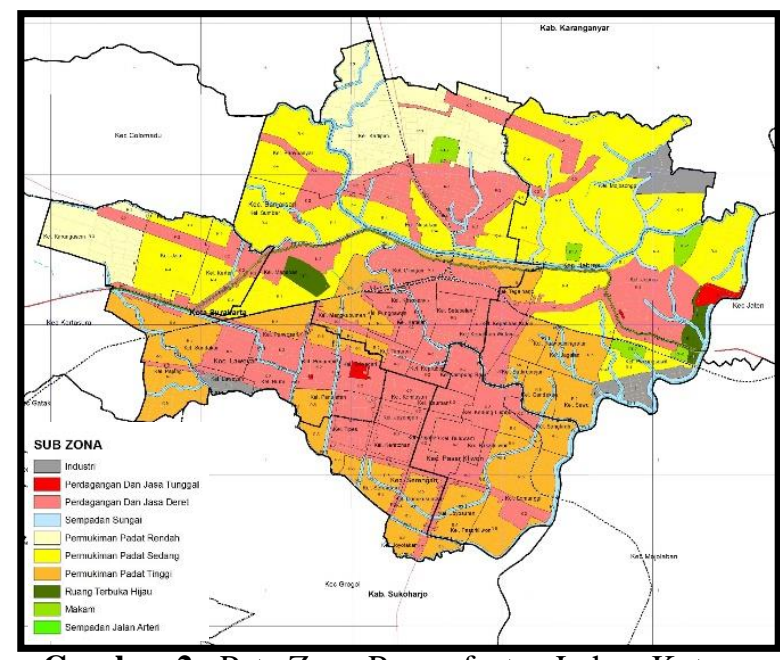

Gambar 2. Peta Zona Pemanfaatan Lahan Kota

Surakarta

Dari persentase diagram dan peta di atas, diketahui bahwa pemanfaatan lahan yang paling mendominasi di Kota Surakarta adalah perdagangan dan jasa deret yang berada di hampir seluruh bagian Surakarta yaitu sebesar $34.9 \%$. Adapun sub zona jenis lainnya yaitu permukiman padat sedang juga hampir mendominasi dengan persentase sebesar $29.9 \%$. Sisanya diikuti oleh pemanfaatan jenis industri, ruang terbuka hijau, makam, sempadan sungai, dan sempadan jalan arteri yang memiliki persentasi hampir sama.

\subsection{Tutupan Vegetasi Tiap Zona Pemanfaatan Lahan}

Setelah mengetahui zonasi yang ada di Surakarta, kemudian zona tersebut dioverlay dengan luasan tutupan vegetasi yang ada di Surakarta untuk mengetahui persebaran tutupan vegetasi di tiap zona pemanfaatan lahan.

Tutupan vegetasi yang tersebar di tiap zona pemanfaatan lahan memiliki persentase sebagai berikut:

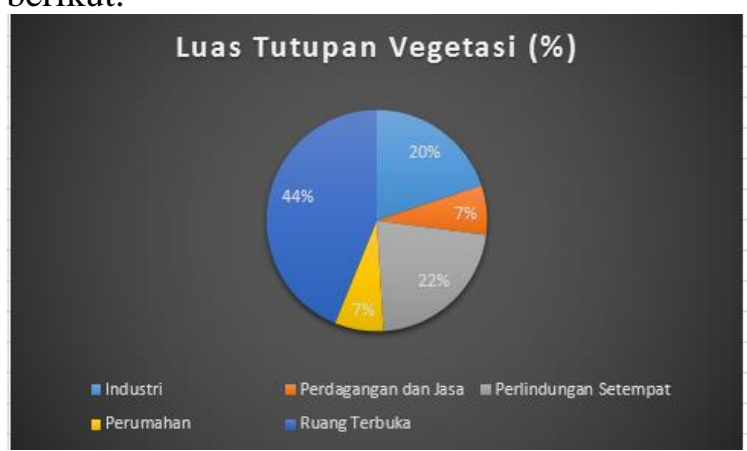

Gambar 2. Persentase Luas Tutupan Vegetasi di Kota Surakarta

Dari diagram di atas, proporsi tutupan vegetasi yang paling banyak terdapat pada zona pemanfaatan lahan ruang terbuka karena dalam zona tersebut minim bangunan dan memiliki potensi yang lebih besar tumbuhnya tutupan vegetasi yaitu sebesar $44 \%$. Sedangkan zona pemanfaatan lahan perlindungan setempat dan industri memiliki tutupan vegetasi eksisting sebesar $22 \%$ dan $20 \%$.

Untuk zona yang paling sedikit ditumbuhi tutupan vegetasi adalah zona perumahan dimana di Kota Surakarta sendiri mayoritas memiliki kepadatan sedang hingga tinggi yang artinya padat bangunan dan sulit untuk ditumbuhi tutupan vegetasi yang hanya sebesar $7 \%$ saja. Kondisi tersebut sama seperti yang ada di zona perdagangan dan jasa.

Untuk jenis tutupan vegetasi yang ada di masing-masing pemanfaatan lahan akan dirinci sebagai berikut.

\subsubsection{Industri}

Pemanfaatan lahan jenis industri yang ada di Kota Surakarta hanya tersebar di Kecamatan Jebres dan Kecamatan Laweyan dengan luas tutupan vegetasi yang ada di dalamnya sebesar $20 \%$ dari total tutupan vegetasi yang ada di Kota Surakarta.

Proporsi tersebut terdiri dari jenis vegetasi pohon, semak, dan rumput dimana vegetasi pohon lebih banyak tersebar di zona tersebut dengan persentase $92 \%$ dan sisanya adalah semak dengan persentase $7 \%$ dan rumput $1 \%$.

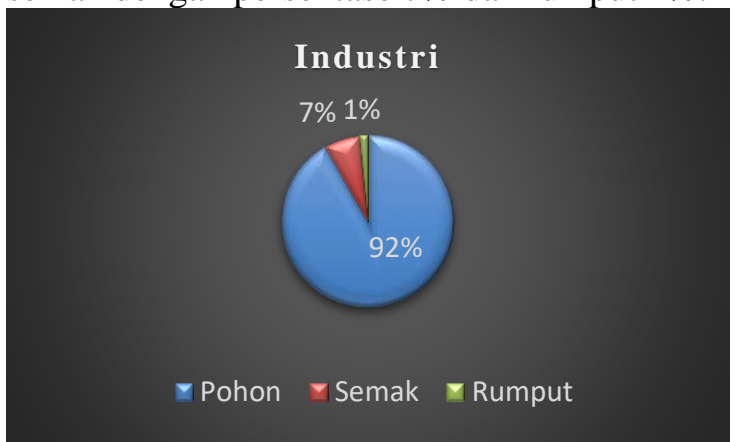

Gambar 3. Persentase Jenis Tutupan Vegetasi di Pemanfaatan Lahan Industri 




Gambar 4. Peta Tutupan Vegetasi di Pemanfaatan Lahan Industri

Bentuk tutupan vegetasi pohon yang ada pada zona ini mayoritas berpola mengelilingi industri yang ada dan juga di dalam kawasannya.

Berikut merupakan jenis tutupan vegetasi yang ada di zona pemanfaatan lahan industri:

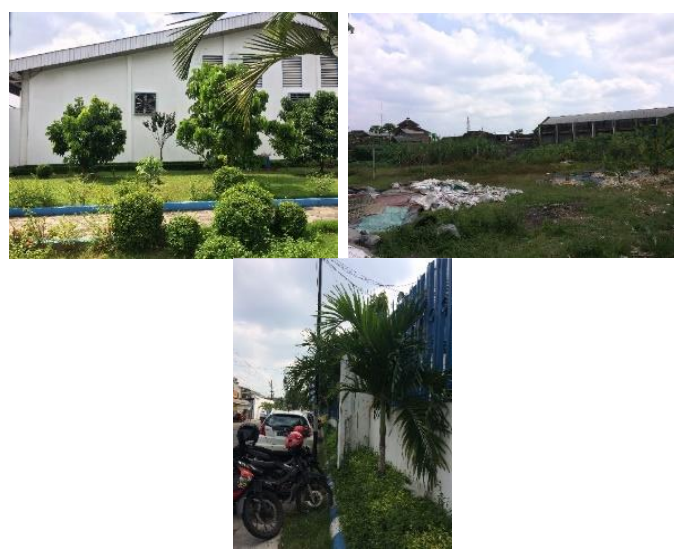

Gambar 5. Jenis Tutupan Vegetasi Eksisting di Pemanfaatan Lahan Industri

\subsubsection{Perdagangan dan Jasa}

Perdagangan dan jasa yang ada di bedakan menjadi 2 jenis yaitu berbentuk deret dan tunggal, namun mayoritas yang ada di Surakarta adalah berbentuk deret di sepanjang kanan kiri jalan arteri, kolektor, maupun lokal. Untuk perdagangan dan jasa jenis tunggal hanya terdapat jenis tutupan vegetasi pohon dan rumput saja dengan persentase pohon $96 \%$ dan rumput $4 \%$.



Gambar 6. Persentase Jenis Tutupan Vegetasi di Pemanfaatan Lahan Perdagangan dan Jasa Tunggal

Sedangkan untuk perdagangan dan jasa jenis deret, tutupan vegetasi yang ada di dalamnya terdapat pohon dengan persentase $85 \%$, semak $2 \%$, rumput $12 \%$, dan sawah $1 \%$.

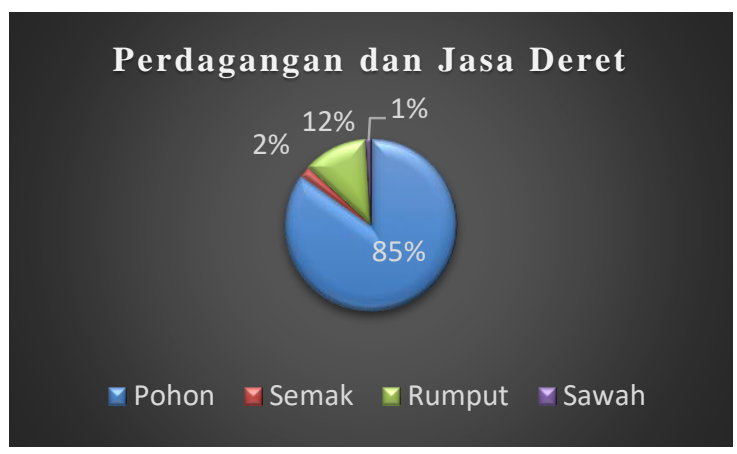

Gambar 7. Persentase Jenis Tutupan Vegetasi di Pemanfaatan Lahan Perdagangan dan Jasa Deret

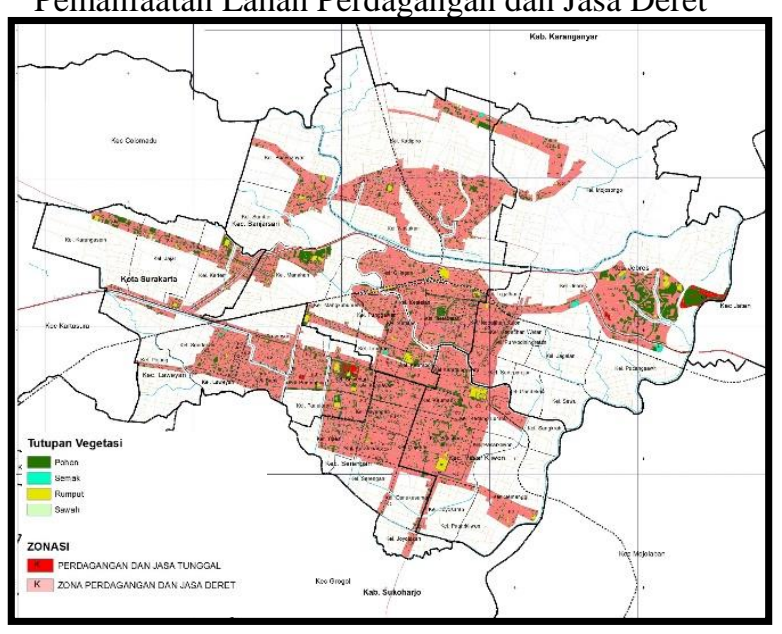

Gambar 8. Peta Tutupan Vegetasi di Pemanfaatan Lahan Perdagangan dan Jasa

Karena perdagangan dan jasa jenis deret lebih besar pemanfaatannya, maka pohon yang ada di deretan perdagangan tersebut selain berfungsi untuk menyerap polusi yang ada, juga bisa dijadikan peneduh. 
Berikut merupakan jenis tutupan vegetasi yang ada di zona pemanfaatan lahan perdagangan dan jasa:

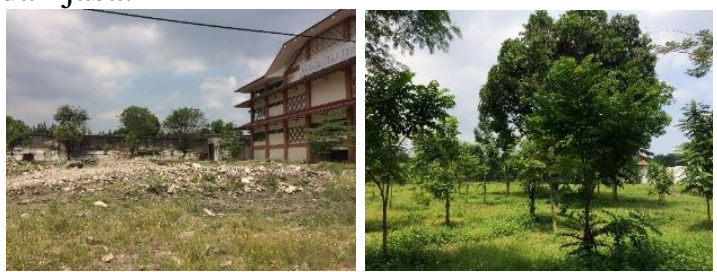

Gambar 9. Jenis Tutupan Vegetasi Eksisting di Pemanfaatan Lahan Perdagangan dan Jasa

\subsubsection{Perlindungan Setempat}

Perlindungan setempat yang dimaksud dalam penelitian ini adalah sempadan sungai, lahan yang ada di kanan kiri sungai biasanya difungsikan sebagai kawasan lindung dengan vegetasi di dalamnya.

Jenis vegetasi yang ada di pemanfaatan lahan ini adalah mayoritas dengan jenis pohon sebesar $94 \%$ dan sisanya semak, rumput, dan sawah sebesar $2 \%$.

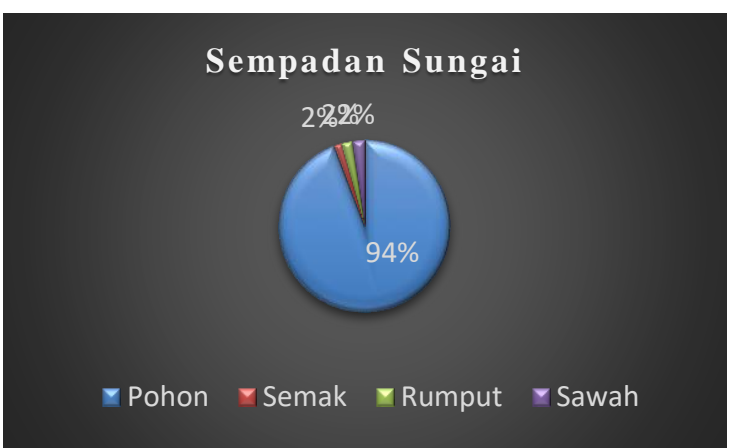

Gambar 10. Persentase Jenis Tutupan Vegetasi di Pemanfaatan Lahan Sempadan Sungai

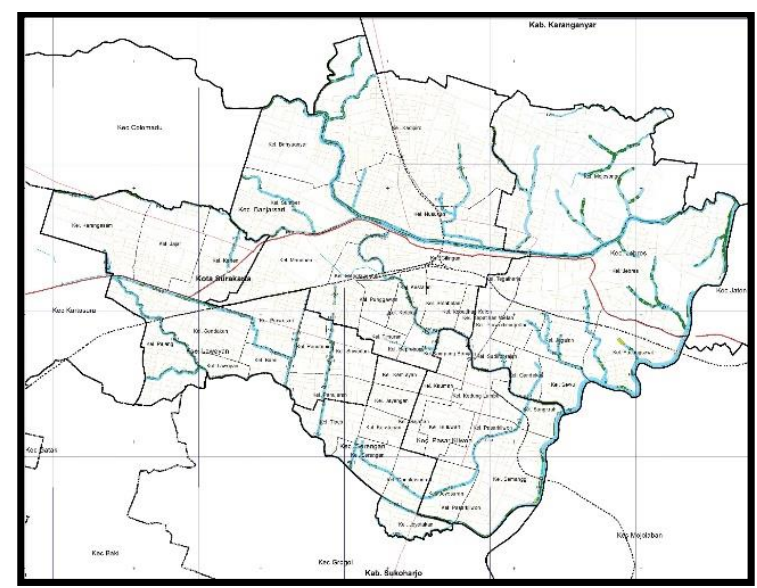

Gambar 11. Peta Tutupan Vegetasi di

Pemanfaatan Lahan Perlindungan Setempat
Berikut merupakan jenis tutupan vegetasi yang ada di zona pemanfaatan lahan perlindungan setempat:

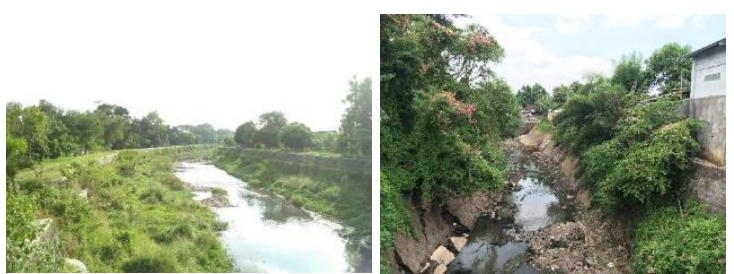

Gambar 12. Jenis Tutupan Vegetasi Eksisting di Pemanfaatan Lahan Perlindungan Setempat

\subsubsection{Perumahan}

Pemanfaatan lahan perumahan di bagi menjadi 3 jenis yaitu permukiman padat rendah, sedang, dan tinggi. Kota Surakarta lebih banyak didominasi permukiman padat sedang hingga tinggi di bagian tengah ke selatan. Untuk bagian utara kerena proses pengembangan, permukiman di bagian tersebut tergolong padat rendah.

Permukiman padat rendah terdiri dari jenis tutupan vegetasi pohon dengan $59 \%$, semak $1 \%$, rumput $12 \%$, dan sawah $28 \%$.

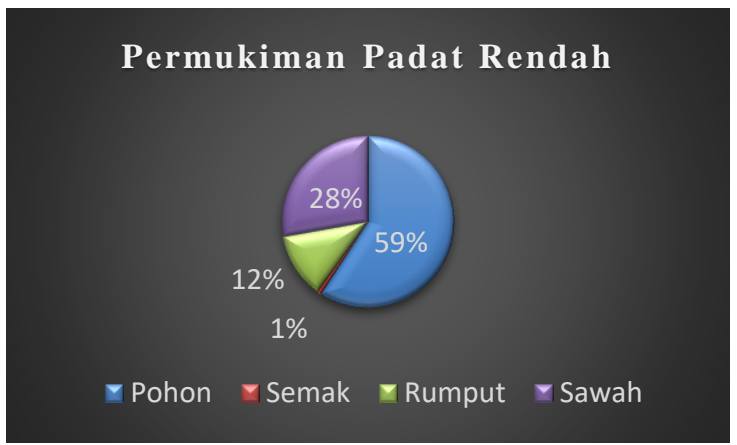

Gambar 13. Persentase Jenis Tutupan Vegetasi di Pemanfaatan Lahan Permukiman Padat Rendah

Untuk permukiman padat sedang proporsi tutupan vegetasinya hampir sama dengan permukiman padat sedang yaitu seperti pada diagram di bawah ini.

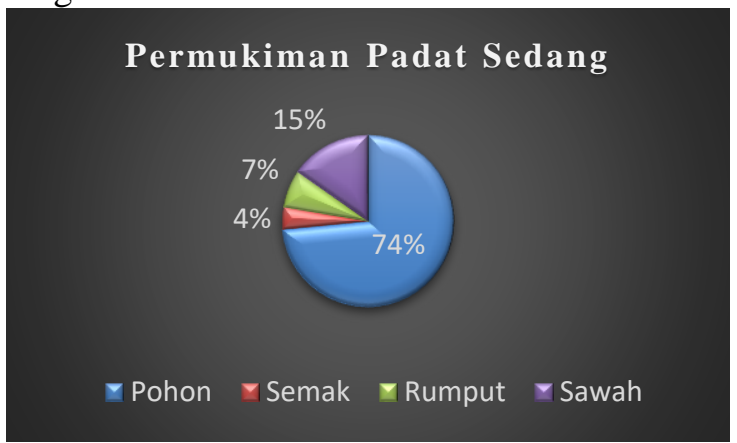


Gambar 14. Persentase Jenis Tutupan Vegetasi di Pemanfaatan Lahan Permukiman Padat Sedang

Tutupan vegetasi yang ada di permukiman padat tinggi terdiri dari pohon dengan $89 \%$, semak $3 \%$, dan rumput $8 \%$.

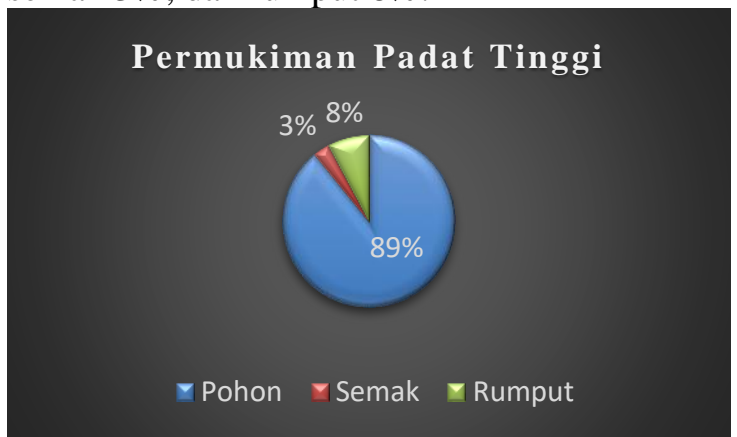

Gambar 15. Persentase Jenis Tutupan Vegetasi di Pemanfaatan Lahan Permukiman Padat Tinggi

Permukiman berkepadatan tinggi mayoritas berupa perkampungan. Terdapat banyak faktor yang berpengaruh terhadap ketersediaan tutupan vegetasi di kampung yaitu keterbatasan lahan, kepadatan bangunan, perubahan penggunaan lahan, dan keterbatasan dana (Rini et al., 2014).

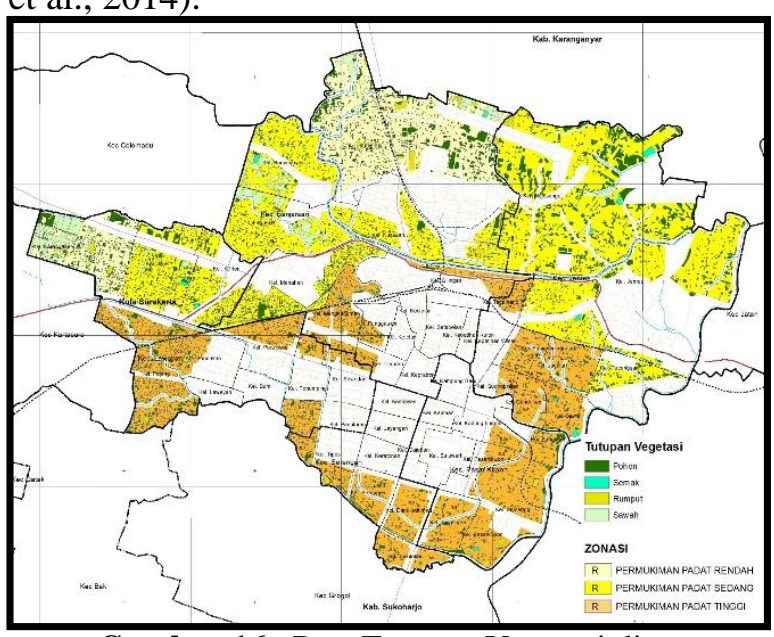

Gambar 16. Peta Tutupan Vegetasi di Pemanfaatan Lahan Perumahan

Berikut merupakan jenis tutupan vegetasi yang ada di zona pemanfaatan lahan perumahan:
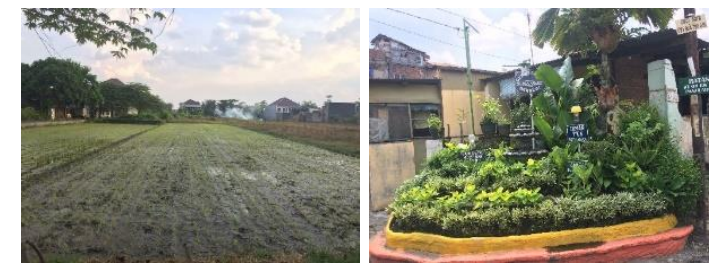

Gambar 17. Jenis Tutupan Vegetasi Eksisting di Pemanfaatan Lahan Perumahan

\subsubsection{Ruang Terbuka}

Pemanfaatan lahan ruang terbuka merupakan zona yang paling tinggi terdapat persebaran tutupan vegetasinya. Terdiri dari 3 jenis pemanfaatan yaitu ruang terbuka hijau, makam, dan sempadan jalan arteri.

Hampir 92\% didominasi oleh tutupan vegetasi pohon dan sisanya semak dan rumput.



Gambar 18. Persentase Jenis Tutupan Vegetasi di Pemanfaatan Lahan Ruang Terbuka Hijau

Untuk makam juga hampir sama dengan ruang terbuka hijau proporsinya, seperti diagram di bawah.

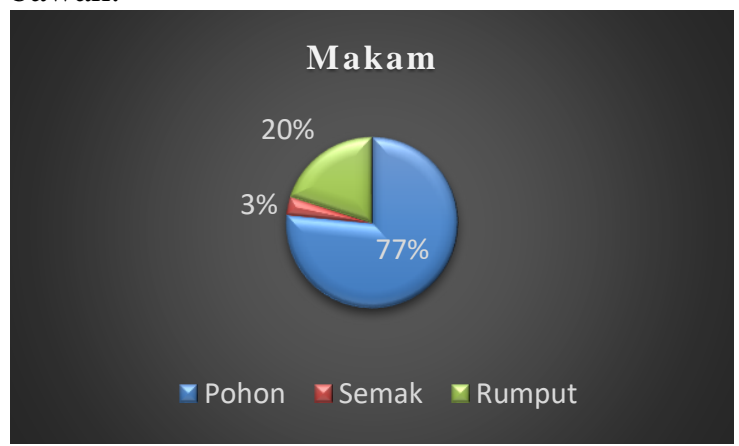

Gambar 19. Persentase Jenis Tutupan Vegetasi di Pemanfaatan Lahan Makam

Sempadan jalan arteri juga merupakan kawasan yang di kanan kirinya diperuntukan untuk ditanami vegetasi. Berikut merupakan proporsi tutupan vegetasi yang ada di sempadan jalan arteri.

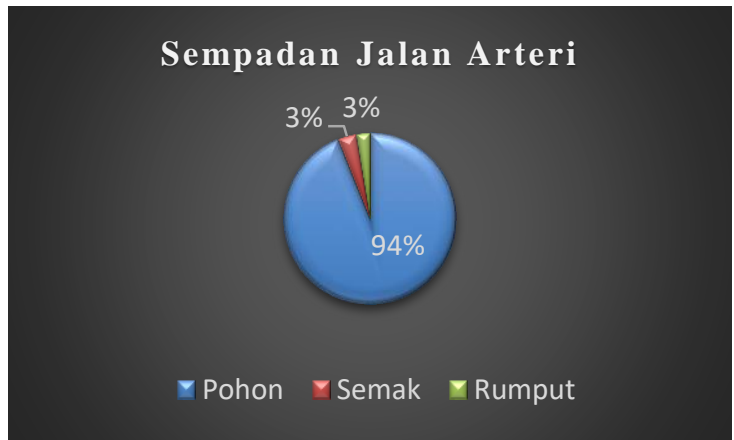

Gambar 20. Persentase Jenis Tutupan Vegetasi di Pemanfaatan Lahan Sempadan Jalan Arteri 


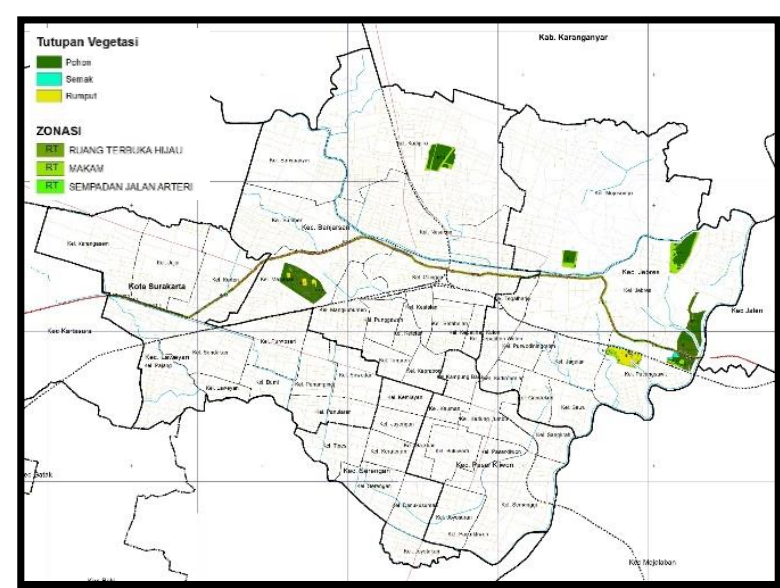

Gambar 21. Peta Tutupan Vegetasi di Pemanfaatan Lahan Ruang Terbuka

Berikut merupakan jenis tutupan vegetasi yang ada di zona pemanfaatan lahan ruang terbuka:

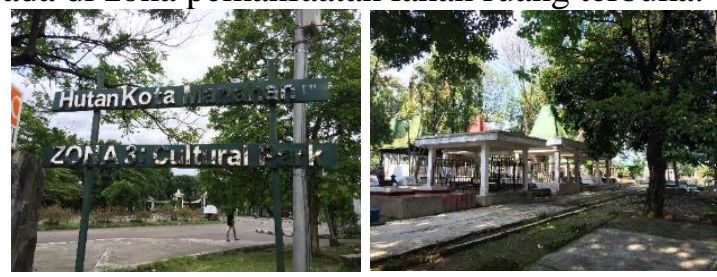

Gambar 22. Jenis Tutupan Vegetasi Eksisting di Pemanfaatan Lahan Ruang Terbuka

\subsection{Tipologi Tutupan Vegetasi pada Tiap Zona Pemanfaatan Lahan}

Setelah mengetahui proporsi tutupan vegetasi di tiap pemanfaatan lahan, kemudian dibahas mengenai tipologi aturan ruang terbuka hijau yang sesuai pada tiap dominasi pemanfaatan lahan.

\subsubsection{Industri}

Tutupan vegetasi pada zona ini adalah rata-rata sebesar 26,79 $\mathrm{Ha}$ atau $20 \%$ dari pemanfaatan lahan industri yang ada di Surakarta. Menurut Materi Teknis RTRW Kota Surakarta Tahun 2011-2031 aturan koefisien daerah hijau yang ada pada dominasi indsutri adalah minimal 30\% dari luas keseluruhan. Hal ini menunjukkan bahwa ketersediaan tutupan vegetasi eksisting yang ada di Surakarta belum memenuhi aturan yang ada.

Namun demikian, ketersediaan tutupan vegetasi eksisting yang ada telah berperan untuk mengendalikan dampak lingkungan yang ada di sekitar industri. Hal tersebut karena hampir $92 \%$ tutupan vegetasi berupa pohon sehingga daya serap untuk menyerap polusi hasil industri pun lebih tinggi dibanding jenis tutupan vegetasi lainnya.
Dominasi industri yang ada di Kecamatan Laweyan basicnya adalah Kampung Batik, sehingga ketersediaan tutupan vegetasinya menyebar di pekarangan-pekarangan bangunan (RTH privat) dalam bentuk tutupan vegetasi pohon. Sedangkan untuk dominasi industri yang ada di Kecamatan Jebres berbentuk taman kecil berupa tutupan vegetasi pohon dan rumput Dan di sekeliling luar industri tersebut terdapat jalur hijau.

\subsubsection{Perdagangan dan Jasa}

Hampir 35\% dari Kota Surakarta didominasi pemanfaatan lahan perdagangan dan jasa. Bentuk dari perdagangan dan jasa yang ada di Surakarta mayoritas berbentuk perdagangan dan jasa deret yang mengikuti bentuk jalan raya dan berada di kanan kiri jalan tersebut, namun juga terdapat beberapa perdagangan dan jasa bentuk tunggal yang persebarannya menyebar di Kota Surakarta.

Pemanfaatan lahan yang mayoritas adalah perdagangan dan jasa tidak sebanding dengan tutupan vegetasi eksisting yang ada yaitu ratarata sebesar 7\% saja. Apabila dibandingnya dengan aturan $\mathrm{KDH}$ minimum yang ada menurut Materi Teknis RTRW Kota Surakarta Tahun 2011-2031 minimal menyediakan 20\% dari luas perdagangan dan jasa hal tersebut belum memenuhi.

Fenomena tersebut dikarenakan lahan kota yang semakin padat sehingga tidak ada runag untuk ruang terbuka hijau. Untuk perdagangan dan jasa jenis tunggal hanya terdapat tutupan vegetasi pohon dan rumput saja karena bentuknya yang tunggal sehingga fungsi vegetasi tersebut untuk peneduh dan estetika di lahan tersebut. Sedangkan perdagangan dan jasa jenis deret karena letaknya yang berada di kanan kiri jalan raya sebagai lalu lintas pergerakan, fungsi adanya pohon, semak, dan rumput adalah untuk mengurangi polusi udara.

\subsubsection{Perlindungan Setempat}

Fungsi utama dari tutupan vegetasi yang ada di zona dominasi penggunaan lahan perlindungan setempat adalah untuk melindungi sungai dari gangguan yang dapat merusak sungai dan lingkungan. Kota Surakarta sendiri memiliki sungai besar maupun sungai-sungai kecil yang mengalir ke permukiman, diantaranya adalah Sungai Bengawan Solo, Kali Pepe Hilir, Kali 
Jenes, Kali Anyar, Kali Gajah Putih, Kali Wingko, Kali Boro, Kali Pelem Wulung, serta Kali Tanggul dengan rata-rata tutupan vegetasi sebesar $84.76 \mathrm{Ha}$ atau $22 \%$ dari luas total.

Eksisting tersebut telah memenuhi $\mathrm{KDH}$ yang ada yaitu minimal $20 \%$ dari luas sempadan sungai yang ada.

Ketersediaan tutupan vegetasi mayoritas berbentuk jenis pohon dengan rata-rata $94 \%$ dari jenis tutupan vegetasi lainnya yaitu semak dan rumput. Fungsi dari adanya pohon di sempadan sungai adalah untuk melindungi dari bencana seperti banjir agar dampaknya tidak terlalu besar. Selain itu, pada dominasi pemanfaatan lahan ini juga terdapat taman kota yang dimanfaatkan oleh pemerintah. Hal ini bertujuan untuk memperindah kota dan mengubah kesan kumuh daerah sekitar sungai yang ada.

\subsubsection{Perumahan}

Rata-rata tutupan vegetasi yang ada di zona ini adalah 7\% dimana eksisting tersebut masih jauh dari aturan minimum $\mathrm{KDH}$ seharusnya sebesar 20\%. Proporsi banyak atau tidaknya ketersediaan tutupan vegetasi di tiap lahan rumah pun berbeda-beda, ada yang ketersediaannya luas karena lahan rumahnya yang besar dan memiliki space sisa untuk ditanami vegetasi, adapun yang sama sekali tidak ada tutupan vegetasi karena padat bangunan dan kondisi tersebut termasuk ke wilayah zona perumahan berkepadatan tinggi.

Selain tutupan vegetasi yang ada di lahan perseorangan, tutupan vegetasi yang ada di zona ini juga berbentuk seperti taman dengan skala pelayanan taman RT, RW, Kelurahan, Kecamatan yang fungsi utamanya untuk memperindah dengan jenis tutupan vegetasi berupa tanaman kecil hingga sedang yang dikelola secara bersama.

Untuk permukiman dengan tingkat kepadatan rendah hingga sedang tutupan vegetasi jenis sawah masih terdapat pada zona tersebut dengan rata-rata $15-28 \%$ dari tutupan vegetasi jenis lainnya yang terletak di bagian utara Kota Surakarta. Sedangkan untuk permukiman padat tinggi jenis vegetasi pohon lebih mendominasi yang letaknya di jalan-jalan lingkungan.

Fungsi dari adanya tutupan vegetasi di zona perumahan sendiri adalah sebagai estetika lingkungan, tutupan vegetasi yang beraneka macam pun memperindah zona tersebut.

\subsubsection{Ruang Terbuka}

Zona ini merupakan zona dengan kondisi eksisting tutupan vegetasi paling banyak dibandingkan dengan zona pemanfaatan lahan lainnya yaitu sebesar $44 \%$. Kondisi tersebut sudah sangat mencukupi dari aturan $\mathrm{KDH}$ minimum $20 \%$ menurut Permen PU No 05/PRT/M/2008.

Hampir separuh dari zona ruang terbuka adalah daerah hijau. Hutan Kota, taman kota, maupun lapangan olahraga di Surakarta merupakan bagian dari zona ruang terbuka dimana didalamnya terdapat tutupan vegetasi pohon, semak, maupun rumput yang fungsinya dapat dinikmati masyarakat sebagai peneduh, bersantai, rekreasi, dan sebagainya.

\section{KESIMPULAN}

Berdasarkan analisis yang telah dilakukan, maka dapat disimpulkan bahwa dominasi pemanfaatan lahan yang paling banyak di Kota Surakarta adalah perdagangan dan jasa jenis deret dengan persentase luas $34.9 \%$ kemudian diikuti dominasi permukiman padat sedang, rendah dan tinggi dengan persentase $29.9 \%$, $17.2 \%$, dan $11.4 \%$. Sisanya adalah dominasi sempadan sungai, industri, ruang terbuka hijau, perdagangan dan jasa tunggal, makam, serta sempadan jalan arteri.

Hal tersebut berbanding terbalik dengan ketersediaan eksisting tutupan vegetasi di tiap dominasi pemafaatan lahan. Eksiting tutupan vegetasi paling banyak ada pada dominasi ruang terbuka yang memang diperuntukkan sebagai ruang yang mewadahi kebutuhan vegetasi. Sedangkan untuk dominasi perdagangan dan jasa serta permukiman ratarata hanya $7 \%$ ketersediaan tutupan vegetasinya.

Fenomena tersebut terjadi karena tiap dominasi pemanfaatan lahan memiliki tipologi tutupan vegetasi yang berbeda-beda. Untuk dominasi seperti perdagangan dan jasa serta pemukiman yang memiliki lahan terbatas, maka tipologi tutupan vegetasinya pun juga terbatas. Namun hal tersebut tidak menutup kemungkinan untuk dapat dikembangkan tutupan vegetasi. Salah satunya dengan pemanfaatan lahan secara vertikal. 
Tipologi tutupan vegetasi di tiap guna lahan akan berpengaruh terhadap pembangunan kota yang berkelanjutan. Aspek ekologis yang tidak terpenuhi karena keterbatasan tutupan vegetasi akan menghambat keberlanjutan pembangunan kota. Oleh karena itu, ketersediaan tutupan vegetasi harus dipenuhi pada setiap dominasi guna lahan.

\section{REFERENSI}

Badan Pusat Statistik Kota Surakarta. 2017. Kota Surakarta dalam Angka Tahun 2017. Surakarta.

DLH. (2015). Penyusunan Dokumen Peta Tutupan Vegetasi dan Ruang Terbuka Hijau Publik Kota Surakarta.

Joga, N., \& Ismaun, I. (2011). RTH 30\%! Resolusi (Kota) Hijau. Jakarta: PT Gramedia Pustaka Utama.

Kusminingrum, N. (2008). Potensi Tanaman dalam Menyerap $\mathrm{CO}_{2}$ dan $\mathrm{CO}$ untuk Mengurangi Dampak Pemanasan Global. Jurnal Permukiman, Vol. 3 No. 2.

Menteri Pekerjaan Umum. 2008. Peraturan Menteri Pekerjaan Umum No. 5 Tahun 2008 tentang Pedoman Penyediaan dan Pemanfaatan Ruang Terbuka Hijau di Kawasan Perkotaan. Jakarta.

Rini, E. F., Sulistyarso, H., Pamungkas, A. (2014). Factors Influencing the Availability of Green Open Space in East Surabaya. Architecture \& Environment, 13(1), 75-92

Walikota Surakarta. 2012. Peraturan Daerah Kota Surakarta No. 1 Tahun 2012 tentang Rencana Tata Ruang Wilayah Kota Surakarta Tahun 2011-2031. Kota Surakarta. 